\title{
PENGGUNAAN MEDIA PEMBELAJARAN KOMIK BERBASIS LITERASI DALAM MENINGKATKATKAN PRESTASI BELAJAR MATERI OFFER AND SUGGESTION
}

\author{
IMAS \\ MAN 1 Ciamis \\ Email : $\underline{\text { imasd4892@gmail.com }}$
}

\begin{abstract}
ABSTRAK
Latar belakang penelitian tindakan kelas adalah loyonya peserta didik MAN 1 Ciamis kelas XI MIPA 3 dalam pembelajaran di masa PTMT karena media pembelajaran yang kurang variatif. Media pembelajaran yang menarik berperan penting sebagai media penyampai pesan pembelajaran yang mampu menumbuhkan prestasi belajar. Salah satu media yang disukai peserta didik adalah komik karena komik memiliki karakteristik sederhana, jelas dan mudah dipahami yang dapat meningkatkan reading, listening, writting, speaking, grammer dan memperluas kosa kata. Komik menjadi lebih bermakna jika berbasis literasi karena mampu mengkomunikasikan kenyataan- kenyataan melalui text, dialogue dan gambar sehingga yang abstrak menjadi konkrit. Materi penelitian adalah offer and suggestion. Subjek penelitian adalah seluruh peserta didik kelas XI MIPA 3 dengan jumlah 21 orang di MAN 1 Ciamis. Penelitian tindakan kelas dilaksanakan dengan dua siklus, setiap siklus terdiri dari dua pertemuan secara luring dengan tahap perencanaan, pelaksanaan, observasi dan refleksi. Hasil penelitian yang diperoleh adalah penggunaan media pembelajaran komik berbasis literasi dapat meningkatkan prestasi belajar peserta didik dengan perolehan hasil yang meningkat. Siklus I dengan rata-rata 69,04, sedangkan ke siklus II rata-rata 92,38 maka terjadi peningkatan $48 \%$.
\end{abstract}

Kata kunci: Media pembelajaran, komik, literasi, dan offer and suggestion.

\section{ABSTRACT}

The background of classroom action research is the lack of students in MAN 1 Ciamis class XI MIPA 3 in learning during PTMT because the learning media is less varied. Attractive learning media plays an important role as a medium for delivering learning messages that are able to grow learning achievement. One of the media that students like is comic because comic has characteristics simple, clear and easy to understand that can improve reading, listening, writing, speaking, grammar and expand vocabulary. Comic becomes more meaningful if they are based on literacy because they are able to communicate facts through text, dialogue and pictures so that the abstract becomes concrete. The research material is offer and suggestion. The research subjects were all students of class XI MIPA 3 with a total of 21 people at MAN 1 Ciamis. Classroom action research was carried out in two cycles, each cycle consisting of two offline meeting in the classroom with the stages of planning, implementing, observing and reflecting. The results of the research obtained was the use of literacy-based comics learning media can improve students' learning achievement by obtaining increased results. Cycle I with an average of 69,04 while to cycle II an average of 92.38 , so there was an increase $48 \%$.

Keywords: Learning media, comics, literacy, and offer and suggestion.

\section{PENDAHULUAN}

Media pembelajaran memiliki andil yang sangat penting dalam pembelajaran. Hal ini dikarenakan media pembelajaran merupakan jembatan untuk menyampaikan pesan. Sehingga mampu meningkatkan hasil belajar peserta didik. Hal ini dapat merangsang minat peserta didik untuk belajar. Semangat dan antusias peserta didik dalam belajar dapat menciptakan suasana belajar yang kondusif.

Surayya (2020) memaparkan bahwa media pembelajaran adalah suatu cara untuk memperlancar pembelajaran. Karena dapat menyampaikan pesan kepada penerima yaitu 
peserta didik. Pesan berupa buku, film, vidio, dan sebagainya. Sehingga tujuan pembelajaran bisa tercapai.

Umar (2014) menjelaskan media pembelajaran merupakan sesuatu yang digunakan untuk merangsang pikiran, perasaan, perhatian, dan kemauan peserta didik yang bisa membangkitkan proses belajar pada pesrta didik. Seperti halnya pendapat Haryono (2014) media pembelajaran adalah sebagai alat yang dapat dipakai untuk menyalurkan pesan, merangsang pikiran, perasaan dan kemauan peserta didik bisa memperluas informasi baru sehingga tercipta suatu proses pembelajaran.

Sementara menurut Daryanto (2020) menjelasakna bahwa media pembelajaran merupakan suatu penyampaian pesan baik untuk manusia, benda dan lingkungan. Hal ini mampu menyampaikan pesan pembelajaran, sehingga media pemebaljaran mampu menumbuhkan minat pikiran dan perasaan peserta didik dimana tujuan pembelajaran akan tercapai. Sedangkan Haryoko (2012) berpendapat bahwa media pembelajaran sebagai alat, metoda, dan teknik. Hal ini dapat memudahkan dalam berkomunikasi terutama antara pendidik dan peserta didik dalam proses pembelajaran, sehingga terjadi pembelajaran yang efektif.

Berdasarkan berbagai pendapat dapat disimpulkan bahwa media pembelajaran adalah suatu cara untuk menyampaikan pesan ke peserta didik baik buku, film, vidio dan sebagainya yang dapat memudahkan interaksi antara guru dan peserta didik sehingga dapat menumbuhkan minat, pikiran, dan perasaan peserta didik dalam mencapai tujuan.

Peranan utama media pembelajaran adalah dapat membantu guru dalam memperjelas materi pembelajaran. Hal ini merupakan transfer pengetahuan dari pendidik kepada peserta didik. Dengan adanya evaluasi dapat mengetahui ketercapaian tujuan pendidikan. Transfer pengetahuan merupakan pemberian informasi yang disampaikan guru kepada peserta didik dalam pembelajaran.

Perbedaan persepsi dapat dijelaskan melalui media pembelajaran sehingga dapat menjembatani misunderstanding untuk menciptakan suasana belajar yang kondusif tanpa adanya tekanan. Untuk memperoleh hasil yang optiimal diperlukan daya dukung. Suasana belajar yang kondusif dapat menentukan keberhasilan peserta didik.

Sudiman (2000) mengatakan tentang klasifikasi media pembelajaran yakni media audio, visual, dan audio visual. Media audio adalah sarana penyampai materi pembelajaran melaui suara suara atau bunyi yang direkam sehinggga bisa didengarkan kembali. Media visual adalah sarana penyampaian materi melalui penglihatan. Media audio visual adalah sarana penyampai pesan melaui pendengaran dan penglihatan sekaligus dalam satu proses pembelajaran.

Setiap aspek kehidupan dipengaruhi oleh tehnologi. Hal ini bersifat simpel sampai yang kompleks. Salah satu media yang digunakan adalah komik. Komik sebagai media penyampai pesan yang dapat dikonsumsi peserta didik. Karena komik dapat dirancang sesuai dengan materi yang akan disampaikan. Kemasan komik yang menarik memungkinkan peserta didik tertarik untuk belajar.

Rohani (1997) menjelaskan media komik adalah media yang bersifat sederhana, jelas, mudah dipahami, dapat memberi sumber informatif dan edukatif. Sedangkan menurut Trimo (1997) mengatakan bahwa media komik memiliki keuntungan dalam proses pembelajaran dinyatakan:

a. Komik memperluas perbendaharaan kosa-kata pembacanya, penambahan warna dalam komik akan membuat fokus dan daya serap ke otak akan meningkat. Peserta didik akan lebih mudah mengingat huruf, kata bahkan kalimat dan menyimpan dalam waktu yang lama.

b. Memperlancar peserta didik memahami hal-hal atau rumusan yang abstrak, kesulitan materi ajar dapat disederhanakan seperti objek-objek yang terlalu besar, berbahaya, atau terlalu jauh untuk dikunjungi dapat dihadirkan melalui media komik. 
c. meningkatkankan minat baca peserta didik, media pembelajaran yang menarik merangsang minat baca peserta didik, terutama cerita komik yang menuntut peserta didik untuk mengetahui sesuatu seperti komik detektif.

d. Alur cerita komik menuju kebaikan, dimana endingnya selalu yang menag itu yang baik dan benar serta tokoh dalam cerita berakhlir bahagia.

Romi (2008) memaparkan bahwa kelebihan dari bacaan berbentuk komik ini telah banyak digunakan oleh negara-negara maju sebagai cara untuk merangsang motivasi baca anak. Sehingga tujuan pembelajaran tercapai secara optimal. Negara Jepang yang telah menggunakan komik sebagai penopang keberhasilan pendidikan.

Levi dan Lentz (dalam Azhar Arsyad, 2005:16) menjelaskan ada empat fungsi media pembelajaran komik yakni media visual, sebagai berikut

1. Fungsi atensi, peserta didik tertarik pada media visual hal utama supaya peserta didik terfokus pada isi pelajaran yang berkaitan dengan makna visual.

2. Fungsi afektif media visual terlihat dari tingkat kenyamanan peserta didik ketika membaca teks yang bergambar. Gambar komik dapat mengganti emosi dan sikap peserta didik.

3. Fungsi kognitif media visual muncul hasil - hasil penelitian yang memaparkan bahwa gambar memperlancar pencapaian tujuan untuk memahami informasi yang tercatat dalam gambar.

4. Fungsi kompensatori media pembelajaran media visual memudahkan peserta didik yang lemah dalam membaca untuk menyimpulkan informasi dalam teks.

Boneff membagi jenis komik Indonesia menjadi tiga pengelompokan, yaitu: (1) komik wayang, komik silat; (2) komik humor; dan (3) komik remaja.

Menurut berbagai pendapat tersebut bahwa komik memiliki sifat yang dapat menumbuhkan rasa senang dan mudah dimengerti sebagian besar peserta didik. Karena komik adalah suatu gambar seni yang menggunakan gambar-gambar tidak bergerak yang membentuk alur cerita yang berhubungan.

Komik akan lebih bermakna apabila berbasis literasi karena mampu mengkomunikasikan kenyataan- kenyataan melalui text, dialogue dan gambar sehingga yang abstrak menjadi konkrit. Yang mampu mendorong peserta didik untuk belajar. Sehingga dengan mudah dipahami oleh peserta didik. Hal ini mampu memperjelas materi pembelajaran yang disampaikan.

Elizabeth Sulzby (1986) memaparkan bahwa literasi adalah suatu kecakapan yang dimiliki seseorang dalam berbahasa. Membaca, berbicara, menyimak dan menulis dengan cara yang bervariasi sesuai dengan targetnya. Dalam meningkatkan pengetahuan dan kecakapan.

Harvey J. Graff (2006) menjelaskan bahwa literasi adalah suatu kecakapan yang dimiliki individu dalam menulis dan membaca. Kemampuan membaca dan menulis sangat diperlukan untuk memahami informasi dengan literasi bisa meraih kemajuan dan kesuksesan.

Kamus online Merriam - Webster menyatakan bahwa literasi ialah suatu kecakapan (melek aksara) yang dimiliki dalam individu dalam keterampilan membaca, menulis dan menguasai materi secara visual. Kemampuan untuk menggunakan bahasa dalam memahami bacaan, mendengarkan, dan mengekpresikan baik lisan atau tulisan.

Secara umum, literasi adalah kecakapan yang dimiliki individu dalam membaca, menulis, berbicara, menghitung, juga memecahkan masalah yang terdapat dalam kehidupan sehari-hari. Dimana literasi tidak dapat dipisahkan dari kecakapan individu dalam memahami bahasa.

Berdasarkan definisi - definisi tersebut bahwa literasi itu bermanfaat dalam memperluas kosa kata, memaksimalkan kapasitas otak dalam membaca dan menulis, menambah ilmu baru, kecakapan individu semakin bagus, merangsang kecakapan verbal, analisis, konsentrasi dan memudahkan dalam menyusun kata juga menulis. Literasi sebagai alat ukur bagi peserta didik dan guru yang mampu mendapatkan pengetahuan yang penting bagi masa depan individu yang unggul dengan adanya tradisi dan budaya literasi. 
Peneliti meneliti materi offer and suggestion. Offer adalah untuk mengespresikan seseorang di depan orang lain untuk melakukan sesuatu seperti May I...? Can I ...? Shall I ...? Would You ...? How about I ...? Sedangkan suggestion adalah memberikan nasihat pada orang lain seperti: Lets... Why don't we ? We could... What about ...? How About...? I suggest that You might want to change ... I think... I don't think...

Berdasarkan hasil pengamatan di lapangan masih menunjukkan banyak peserta didik kurang bergairah, loyo juga merasa bosan dalam belajar yang hanya karena media pembelajaran yang dipakai kurang menarik sehingga mengakibatkan hasil belajar peserta didik kurang memuaskan dengan nilai ketuntasan minimal 75 dalam kenyataannya masih ada peserta didik belum mencapai KKM. Penulis membuat solusi atas permasalahan tersebut melalui "penggunaan media pembelajaran komik berbasis literasi dalam meningkatkan prestasi pada materi offer and suggestion MAN 1 Ciamis kelas XI MIPA 3”.

\section{METODE PENELITIAN}

Penelitian ini merupakan Penelitian Tindakan Kelas (PTK) yang dilaksanakan pada kelas XI MIPA 3 MAN 1 Ciamis Provinsi Jawa Barat. Subjek penelitian ini seluruh peserta didik kelas XI MIPA 3 dengan jumlah siswa 21 peserta didik semuanya perempuan. Pemilihan kelas didasarkan atas adanya permasalahan yang dihadapi guru dalam meningkatkan prestasi belajar. Penelitian ini dilakukan dalam pembelajaran PTMT dan tidak mengganggu pembelajaran. Hal ini dilakukan di semester ganjil tahun ajaran 2021/2022. Sedangkan waktu tindakan sesuai alokasi silabus MAN 1 Ciamis dan kebijakan kepala madrasah alokasi waktu di masa PTMT ialah 2 X 30 menit.

Objek penelitian adalah pembelajaran mata pelajaran bahasa Inggris dalam materi offer and suggestion dengan menggunakan model problem based learning.

\section{HASIL DAN PEMBAHASAN}

\section{Hasil}

Siklus 1

1. Perencanaan Siklus 1

Pada tahap perencanaan peneliti mempersiapkan RPP, komik phyxton dengan materi offer and suggestion yang sesuai dengan karakteristik MAN 1 Ciamis dengan alokasi waktu 2x30 menit, penyusunan butir soal untuk menilai prestasi peserta didik dan lembar observasi untuk menilai sikap peserta didik selama pembelajaran. Peneliti meminta 2 guru mata pelajaran yang sama (teman sejawat) membantu mengobservasi aktivitas belajar peserta didik untuk mengetahui kekurangankekurangan. Pertemuan pertama PTK siklus I di masa PTMT dilaksanakan pada hari Senin tanggal 2 Agustus 2021 selama 30 menit. Pembelajaran dimulai jam 09.40 sampai 10.10 WIB, dan pertemuan ke kedua hari Rabu tanggal 4 Agustus2021 60 menit. Penelitian siklus II Senin tanggal Agustus dan Rabu tanggal Agustus 2021.

2. Penelitian Tindakan Kelas Siklus I

Pelaksanaan siklus I peneliti minta bantuan teman sejawat untuk menjadi observer sebagai team teaching. Langkah-langkah penelitian tindakan kelas sebagai berikut:

a. Pendahuluan

- Guru mengucapkan salam.

- Berdo'a dipinpin oleh ketua kelas.

- Membaca al-qur'an bersama.

- Mengecek kehadiran siswa.

- Memberikan ice breaking.

- Menyampaikan tujuan pembelajaran.

b. Kegiatan Inti

- Memberikan apersepsi. 
- Menayangkan komik offer and suggestion.

- Tanya jawab kata sulit.

- Siswa membaca komik.

- Membentuk kelompok dengan anggota 4 orang.

- Sharing hasil diskusi.

- Mmberi kesempatan peserta didik untuk mengungkapkan offer and suggestion dan peserta didik lain memberikan jawabannya.

c. Penutup

- Evaluasi PTK siklus I.

- Guru bersama siswa menyimpulkan materi pembelajaran.

- Salam penutup.

3. Observasi

Observasi dilakukan pada waktu pembelajaran dengan memberikan 10 butir soal objektif sedangkan evaluasi diberikan pada ahir siklus I dengan diikuti oleh 21 orang siswa sesuai jumlah kelas XI MIPA 3. Rekapitulasi hasil tes disajikan dalam tabel berikut ini.

Tabel 1 : Hasil pengolahan data

\begin{tabular}{|c|c|c|c|c|c|c|c|c|c|c|c|c|c|}
\hline \multicolumn{11}{|c|}{ Butir Soal } & \multirow[t]{2}{*}{ Skor } & \multirow[t]{2}{*}{ Nilai } & \multirow[t]{2}{*}{ keterangan } \\
\hline NO & 1 & 2 & 3 & 4 & 5 & 6 & 7 & 8 & 9 & 10 & & & \\
\hline 1 & 1 & 1 & 0 & 1 & 1 & 1 & 1 & 0 & 1 & 0 & 7 & 70 & $\begin{array}{l}\text { Belum } \\
\text { Tuntas }\end{array}$ \\
\hline 2 & 0 & 1 & 1 & 1 & 1 & 1 & 1 & 0 & 1 & 0 & 7 & 70 & $\begin{array}{l}\text { Belum } \\
\text { Tuntas }\end{array}$ \\
\hline 3 & 1 & 1 & 1 & 1 & 1 & 1 & 1 & 0 & 1 & 0 & 8 & 80 & Tuntas \\
\hline 4 & 1 & 1 & 0 & 1 & 1 & 1 & 0 & 0 & 1 & 0 & 6 & 60 & $\begin{array}{l}\text { Belum } \\
\text { Tuntas }\end{array}$ \\
\hline 5 & 1 & 0 & 1 & 1 & 1 & 1 & 1 & 0 & 1 & 0 & 7 & 70 & $\begin{array}{l}\text { Belum } \\
\text { Tuntas }\end{array}$ \\
\hline 6 & 1 & 1 & 1 & 1 & 1 & 1 & 1 & 0 & 1 & 1 & 8 & 80 & Tuntas \\
\hline 7 & 1 & 1 & 1 & 1 & 1 & 1 & 1 & 0 & 1 & 0 & 8 & 80 & Tuntas \\
\hline 8 & 1 & 1 & 1 & 1 & 1 & 1 & 1 & 0 & 1 & 0 & 8 & 80 & Tuntas \\
\hline 9 & 1 & 1 & 0 & 1 & 1 & 1 & 1 & 0 & 0 & 0 & 6 & 60 & $\begin{array}{l}\text { Belum } \\
\text { Tuntas }\end{array}$ \\
\hline 10 & 1 & 1 & 1 & 1 & 1 & 1 & 1 & 0 & 1 & 0 & 8 & 80 & Tuntas \\
\hline 11 & 1 & 0 & 1 & 1 & 1 & 1 & 0 & 0 & 1 & 0 & 6 & 60 & $\begin{array}{l}\text { Belum } \\
\text { Tuntas }\end{array}$ \\
\hline 12 & 1 & 1 & 1 & 1 & 1 & 1 & 0 & 0 & 0 & 0 & 6 & 60 & $\begin{array}{l}\text { Belum } \\
\text { Tuntas }\end{array}$ \\
\hline 13 & 1 & 1 & 1 & 1 & 1 & 1 & 1 & 0 & 0 & 0 & 7 & 70 & $\begin{array}{l}\text { Belum } \\
\text { Tuntas }\end{array}$ \\
\hline 14 & 1 & 1 & 1 & 0 & 1 & 1 & 1 & 0 & 1 & 0 & 7 & 70 & $\begin{array}{l}\text { Belum } \\
\text { Tuntas }\end{array}$ \\
\hline 15 & 1 & 1 & 1 & 1 & 1 & 1 & 0 & 0 & 1 & 0 & 7 & 70 & $\begin{array}{l}\text { Belum } \\
\text { Tuntas }\end{array}$ \\
\hline 16 & 1 & 1 & 1 & 1 & 1 & 1 & 1 & 0 & 1 & 0 & 8 & 80 & Tuntas \\
\hline 17 & 1 & 1 & 1 & 1 & 1 & 1 & 1 & 1 & 1 & 0 & 8 & 80 & Tuntas \\
\hline 18 & 1 & 1 & 1 & 1 & 0 & 1 & 1 & 0 & 1 & 1 & 7 & 70 & $\begin{array}{l}\text { Belum } \\
\text { Tuntas }\end{array}$ \\
\hline 19 & 1 & 1 & 1 & 1 & 1 & 1 & 1 & 0 & 1 & 0 & 8 & 80 & Tuntas \\
\hline 20 & 1 & 1 & 1 & 1 & 1 & 1 & 1 & 1 & 1 & 0 & 8 & 80 & Tuntas \\
\hline 21 & 1 & 1 & 1 & 1 & 1 & 1 & 1 & 0 & 1 & 0 & 8 & 80 & Tuntas \\
\hline
\end{tabular}




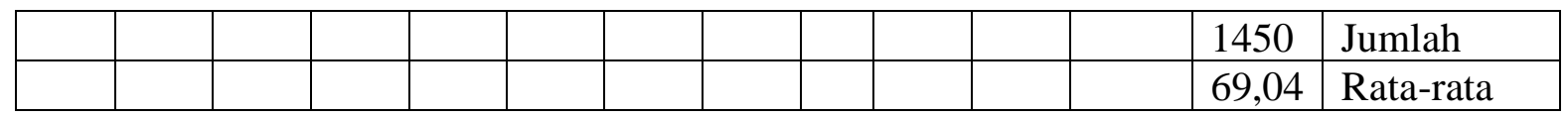

Pada siklus I jumlah rata-rata peserta didik XI MIPA 3 MAN 1 Ciamis pada materi offer and suggestion sebesar 69,04 dengan rentan skor 60 sampai 80. Jumlah peserta didik yang tuntas di atas kkm 75 sebanyak 11 orang dengan persentase $52 \%$. Profil ketuntasan disajikan pada tabel berikut.

Tabel 2: Analis Soal

\begin{tabular}{|l|l|l|}
\hline Aspek Analisis & Hasil Perhitungan & Keterangan \\
\hline Skor Maksimum & 80 & \\
\hline Skor Minimum & 60 & \\
\hline Jumlah & 1450 & \\
\hline Rata-rata & 69 & Belum Tuntas \\
\hline Daya Serap & 69,04 & Belum Tuntas \\
\hline Jumlah Siswa Tuntas & 11 & \\
\hline Ketuntasan Belajar & 52 & \\
\hline
\end{tabular}

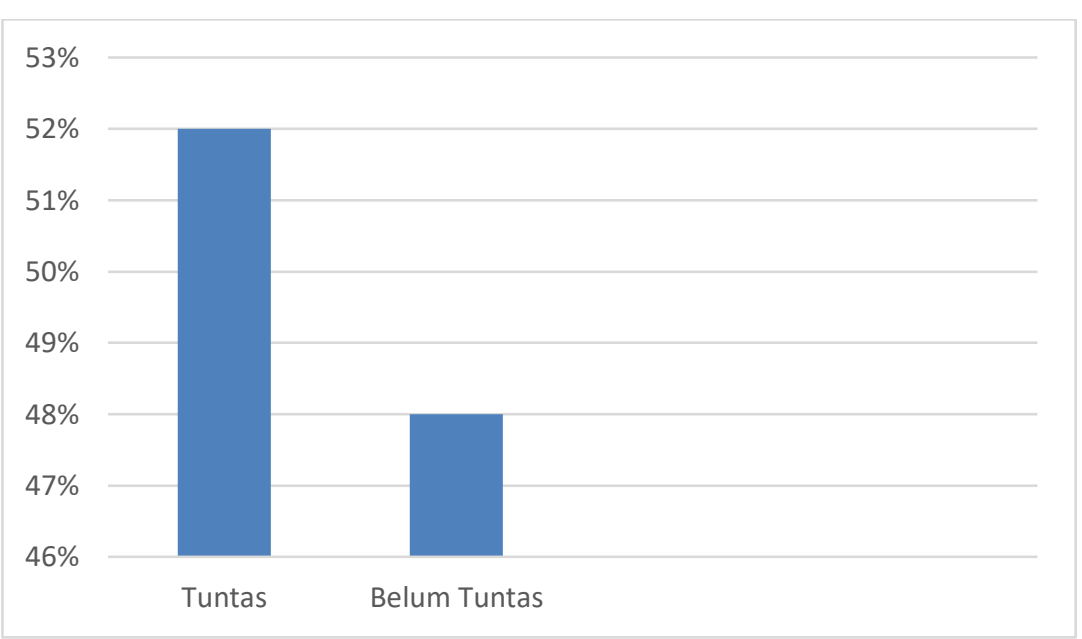

Gambar 1. Grafik Siklus I

Grafik ketuntasan belajar siklus 1 sebesar $52 \%$ masih ada $48 \%$ belum tuntas sebanyak 10 orang peserta didik di bawah ketuntasan minimal yang sudah ditetapkan.
4. Refleksi

Berdasrkan hasil penelitian ketuntasan belajar peserta didik baru mencapai $52 \%$, maka dilanjutkan ke siklus II, sedangkan kelemahan dan keunggulan tindakan pada siklus I adalah sebagai berikut.

1) Peserta didik menemukan kata-kata sulit dalam media pembelajaran komik karena media pembelajaran ini bagi peserta didik. Dibuktikan dengan pertanyaan peserta didik tentang kata sulit yang ditemukan.

2) Peserta didik masih salah mengucapkan kata-kata yang ada di komik.

3) Saat menyajikan hasil diskusi masih ada peserta didik yang masih tidak mendengarkan. Keunggulan dari pelaksanaan tindakan siklus I

1) Media pembelajaran komik sangat disenangi peserta didik dan membaca isi komik sampai selesai.

2) Isi cerita di komik bener-bener sesuai dengan kehidupan peserta didik.

3) Peserta didik ingin membuat komik.

Tabel 3. Pengolahan Data

\begin{tabular}{|l|l|l|l|l|l|l|l|l|l|l|l|l|l|}
\hline & \multicolumn{10}{|c|}{ Skor } & Nilai & \\
\cline { 1 - 13 } NO & $\mathbf{1}$ & $\mathbf{2}$ & $\mathbf{3}$ & $\mathbf{4}$ & $\mathbf{5}$ & $\mathbf{6}$ & $\mathbf{7}$ & $\mathbf{8}$ & $\mathbf{9}$ & $\mathbf{1 0}$ & & & keterangan \\
\hline 1 & 1 & 1 & 0 & 1 & 1 & 1 & 1 & 0 & 1 & 1 & 8 & 80 & Tuntas \\
\hline 2 & 1 & 1 & 1 & 1 & 1 & 1 & 1 & 0 & 1 & 0 & 8 & 80 & Tuntas \\
\hline 3 & 1 & 1 & 1 & 1 & 1 & 1 & 1 & 1 & 1 & 1 & 10 & 100 & Tuntas \\
\hline
\end{tabular}


Vol 2. No 1. Januari 2022 P-ISSN : 2774-8022, e-ISSN : 2774-5791

\begin{tabular}{|l|l|l|l|l|l|l|l|l|l|l|l|l|l|}
\hline 4 & 1 & 1 & 1 & 1 & 1 & 1 & 0 & 0 & 1 & 0 & 8 & 80 & Tuntas \\
\hline 5 & 1 & 1 & 1 & 1 & 1 & 1 & 1 & 1 & 1 & 1 & 10 & 100 & Tuntas \\
\hline 6 & 1 & 1 & 1 & 1 & 1 & 1 & 1 & 0 & 1 & 1 & 9 & 90 & Tuntas \\
\hline 7 & 1 & 1 & 1 & 1 & 1 & 1 & 1 & 1 & 1 & 0 & 9 & 90 & Tuntas \\
\hline 8 & 1 & 1 & 1 & 1 & 1 & 1 & 1 & 1 & 1 & 1 & 10 & 100 & Tuntas \\
\hline 9 & 1 & 1 & 1 & 1 & 1 & 1 & 1 & 0 & 1 & 0 & 8 & 80 & Tuntas \\
\hline 10 & 1 & 1 & 1 & 1 & 1 & 1 & 1 & 1 & 1 & 1 & 10 & 100 & Tuntas \\
\hline 11 & 1 & 1 & 1 & 1 & 1 & 1 & 1 & 0 & 1 & 0 & 8 & 80 & Tuntas \\
\hline 12 & 1 & 1 & 1 & 1 & 1 & 1 & 1 & 0 & 0 & 0 & 8 & 80 & Tuntas \\
\hline 13 & 1 & 1 & 1 & 1 & 1 & 1 & 1 & 1 & 0 & 0 & 8 & 80 & Tuntas \\
\hline 14 & 1 & 1 & 1 & 0 & 1 & 1 & 1 & 1 & 1 & 1 & 9 & 90 & Tuntas \\
\hline 15 & 1 & 1 & 1 & 1 & 1 & 1 & & 0 & 1 & 0 & 8 & 80 & Tuntas \\
\hline 16 & 1 & 1 & 1 & 1 & 1 & 1 & 1 & 0 & 1 & 1 & 8 & 90 & Tuntas \\
\hline 17 & 1 & 1 & 1 & 1 & 1 & 1 & 1 & 0 & 1 & 0 & 8 & 80 & Tuntas \\
\hline 18 & 1 & 1 & 1 & 1 & 0 & 1 & 1 & 0 & 1 & 1 & 8 & 80 & Tuntas \\
\hline 19 & 1 & 1 & 1 & 1 & 1 & 1 & 1 & 1 & 1 & 1 & 9 & 100 & Tuntas \\
\hline 20 & 1 & 1 & 1 & 1 & 1 & 1 & 1 & 1 & 1 & 1 & 9 & 100 & Tuntas \\
\hline 21 & 1 & 1 & 1 & 1 & 1 & 1 & 1 & 0 & 1 & 1 & 9 & 90 & Tuntas \\
\hline & & & & & & & & & & & & 1940 & Jumlah \\
\hline & & & & & & & & & & & & 92,38 & Rata-rata \\
\hline
\end{tabular}

Hasil pengolahan data menunjukkan bahwa pada siklus II jumlah rata-rata peserta didik XI MIPA 3 MAN 1 Ciamis pada materi offer and suggestion sebesar 92,38 dengan rentan skor 80 sampai 100. Semua peserta didik tuntas di atas kkm 75 sebanyak 21 orang dengan persentase $100 \%$. Profil ketuntasan disajikan pada tabel berikut.

Tabel 4. Analisis Data

\begin{tabular}{|l|l|l|}
\hline Aspek Analisis & Hasil Perhitungan & Keterangan \\
\hline Skor Maksimum & 100 & \\
\hline Skor Minimum & 80 & \\
\hline Jumlah & 1940 & \\
\hline Rata-rata & 93 & Tuntas \\
\hline Daya Serap & 92,38 & Tuntas \\
\hline Jumlah Siswa Tuntas & 21 & \\
\hline Ketuntasan Belajar & $100 \%$ & \\
\hline
\end{tabular}

Tabel 4 menunjukkan rentan nilai 80-100 dengan rata-rata 92,38 dan semua peserta didik sudah tuntas di atas KKM 75.

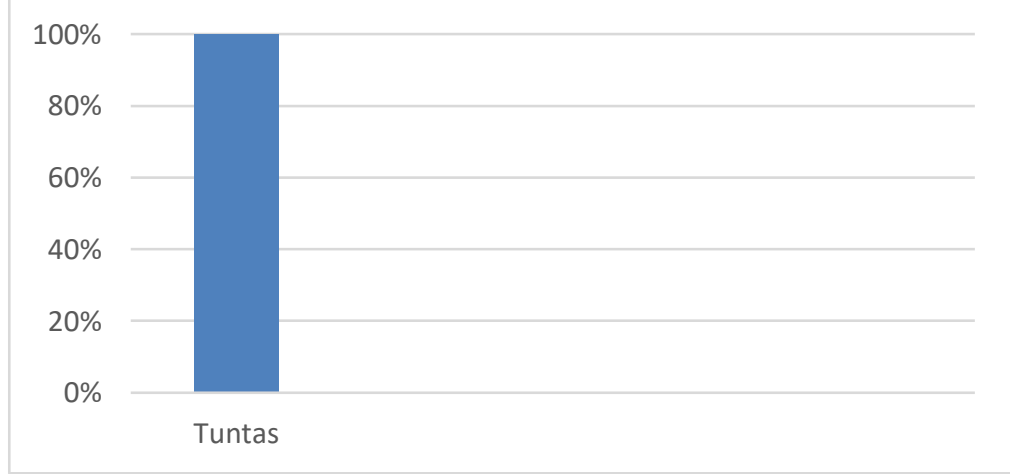

\section{Gambar 2. Grafik Siklus II}

Grafik ketuntasan belajar siklus II sebesar $100 \%$ tuntas sebanyak 21 orang peserta didik di atas ketuntasan minimal yang sudah ditetapkan. 
Tabel 5. Pengolahan Data siklus I dan II

\begin{tabular}{|l|l|l|l|l|}
\hline & Siklus 1 & & Siklus II & \\
\hline No & Nilai & Ketuntasan & Nilai & Ketuntasan \\
\hline 1 & 70 & Belum Tuntas & 80 & Tuntas \\
\hline 2 & 70 & Belum Tuntas & 80 & Tuntas \\
\hline 3 & 80 & Tuntas & 100 & Tuntas \\
\hline 4 & 60 & Belum Tuntas & 80 & Tuntas \\
\hline 5 & 70 & Belum Tuntas & 100 & Tuntas \\
\hline 6 & 80 & Tuntas & 90 & Tuntas \\
\hline 7 & 80 & Tuntas & 90 & Tuntas \\
\hline 8 & 80 & Tuntas & 100 & Tuntas \\
\hline 9 & 60 & Belum Tuntas & 80 & Tuntas \\
\hline 10 & 80 & Tuntas & 100 & Tuntas \\
\hline 11 & 60 & Belum Tuntas & 80 & Tuntas \\
\hline 12 & 60 & Belum Tuntas & 80 & Tuntas \\
\hline 13 & 70 & Belum Tuntas & 80 & Tuntas \\
\hline 14 & 70 & Belum Tuntas & 90 & Tuntas \\
\hline 15 & 70 & Belum Tuntas & 80 & Tuntas \\
\hline 16 & 80 & Tuntas & 90 & Tuntas \\
\hline 17 & 80 & Tuntas & 80 & Tuntas \\
\hline 18 & 70 & Belum Tuntas & 80 & Tuntas \\
\hline 19 & 80 & Tuntas & 100 & Tuntas \\
\hline 20 & 80 & Tuntas & 100 & Tuntas \\
\hline 21 & 80 & Tuntas & 90 & Tuntas \\
\hline
\end{tabular}

Tabel 5 menunjukkan rekap perbandingan pengolahan data siklus I dan II.

\begin{tabular}{|c|c|c|c|c|}
\hline \multirow{2}{*}{$\begin{array}{l}\text { Aspek yang } \\
\text { dibandingkan }\end{array}$} & Siklus I & \multirow[t]{2}{*}{ Keterangan } & Siklus II & \multirow[t]{2}{*}{ Keterangan } \\
\hline & Nilai & & Nilai & \\
\hline Jumlah & 1450 & & 1940 & \\
\hline Rata-rata & 69 & Belum Tuntas & 92,4 & Tuntas \\
\hline Daya Serap & $69,04 \%$ & Belum Tuntas & $92,38 \%$ & Tuntas \\
\hline Ketuntasan & 52 & Belum Tuntas & $100 \%$ & Tuntas \\
\hline
\end{tabular}

Berdasrkan Gambar 3 menunjukkan bahwa terjadi peningkatan prestasi belajar dengan jumlah rata-rata di siklus I 69,04 dan di siklus II 92,38 dan terjadi peningkatan sebesar $48 \%$.

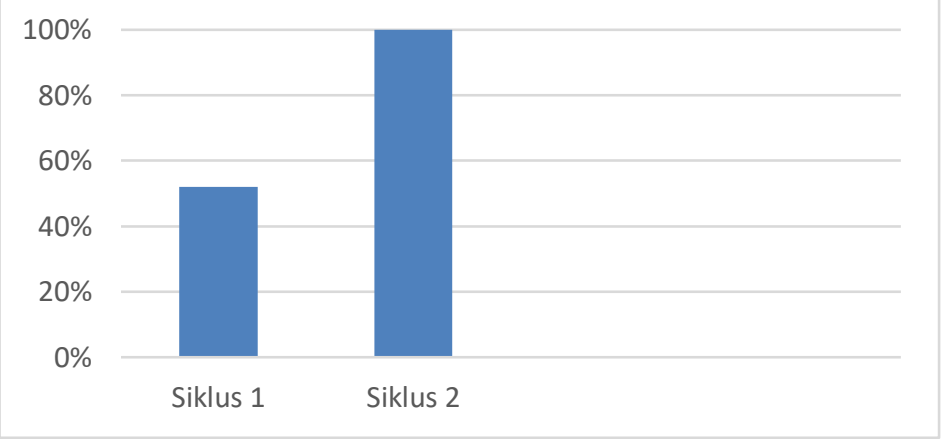

Gambar 3. Ketuntasan Siklus I dan II

Berdasarkan hasil penelitian yang dilakukan dalam dua siklus dimana terjadi peningkatan hasil. Rata-rata hasil belajar di silkus I $52 \%$ sedangkan siklus II $100 \%$. Dikarenakan pembelajaran di siklus II dilaksanakan lebih optimal berdasarkan kelemahan dan keunggulan di siklusI. Peningkatan rata-rata, daya serap, dan ketuntasan siklus I dan siklus II. 


\section{Pembahasan}

Berdasarkan hasil penelitian yang dilakukan dalam dua siklus, menunujukkan hasil bahwa adanya peningkatan hasil belajar pelajaran bahasa Inggris pada materi offer and Suggestion di kelas XI MIPA 3. Hasil penelitian ini sesuai dengan pendapat Kadek (2021) menyampaikan bahwa media pembelajaran komik dalam pelajaran bahasa Inggris dapat meningkatkan motivasi berprestasi siswa dan hasil belajar. Penelitian lainnya Esthy dan Emy (2017) menyatakan bahwa terjadi adanya peningkatan hasi belajar melalui media komik strip. Selanjutnya Sasti (2018) menyampaikan bahwa media komik pada pelajaran bahasa Inggris dapat meningkatkan membaca pemahaman peserta didik. I

\section{KESIMPULAN}

Kesimpulan dari hasil penelitian di atas bahwa penggunaan media pembelajaran komik berbasis literasi dapat meningkatkan prestasi belajar peserta didik pada materi offer and suggestion kelas XI MIPA 3 di MAN 1 Ciamis tahun pelajaran 2021/2022. Rata-rata hasil belajar bahasa Inggris pada materi offer and suggestion pada siklus I 69,04 ke siklus II menjadi 92,38 dengan ketuntasan $52 \%$ di siklus I menjadi 100\% di siklus II. Penelitian ini menunjukan peningkatan sebesar $48 \%$.

\section{DAFTAR PUSTAKA}

Andra Tresiana.(2018). Metoda penelitian. book.google.com.

Astuti, P. (2018). Peningkatan Kemampuan Membaca Pemahaman Bahasa Inggris Melalui Media Komik Berbahasa Inggris Pada Siswa Kelas Viii Mts. Perspektif Ilmu Pendidikan, 32(1), 1-6.

Aulia, J., Zarkasih, Z., \& Nova, T. L. (2020). Meta-Analisis Pengaruh Penerapan Pendekatan Saintifik Berbantuan Komik terhadap Hasil Belajar IPA Siswa SMP. Journal of Natural Science and Integration, 3(1), 70-76.

Farid A, \& Hamidulloh I \& Dian A W. (2018). Media literasi sekolah. book.google.com.

Karmiani, S. (2018). Penggunaan Media Komik Berbahasa Inggris Sebagai Upaya Meningkatkan Kemampuan Membaca Pemahaman Bahasa Inggris Pada Siswa Kelas Viii Smpn 3 Teluk Kuantan. Jurnal Pajar (Pendidikan dan Pengajaran), 2(6), 883890.

Muchyidin, A. (2017). Pengaruh penggunaan bahan ajar matematika bersuplemen komik terhadap kemandirian belajar siswa. Eduma: Mathematics Education Learning and Teaching, 6(1), 43-51.

Nugraheni, N. (2017). Penerapan media komik pada pembelajaran matematika di Sekolah Dasar. Refleksi Edukatika: Jurnal Ilmiah Kependidikan, 7(2).

Pritandhari, M. (2016). Penerapan Komik Strip Sebagai Media Pembelajaran Mata Kuliah Manajemen Keuangan Mahasiswa Universitas Muhammadiyah Metro. PROMOSI: Jurnal Program Studi Pendidikan Ekonomi, 4(2).

Ramen A Purba \& Imam Rofiki \& Suharman Purba (2020). Pengantar media pembelajara. book.google.com.

Ramliyana, R. (2016). Penerapan media komik pada pembelajaran BIPA (Studi Kasus pada peserta Korea tingkat pemula di Universitas Trisakti Jakarta). SAP (Susunan Artikel Pendidikan), 1(1).

Rudy Humiharsono \& Hisbiyatul Hasanah \& Dedi Ariyanto. (2017). Media pembelajaran. book.google.com.

Setiawan G Sasongko. (2021). Mendongkrak kecerdasan anak dengan komik. book.google.co.id. 